\title{
Effect of Crop Rotation on Take-all of Wheat in Double-Cropping Systems
}

\author{
Barry M. Cunfer, Department of Plant Pathology, G. David Buntin, Department of Entomology, and Daniel V. \\ Phillips, Department of Plant Pathology, University of Georgia, Griffin 30223
}

\begin{abstract}
Cunfer, B. M., Buntin, G. D., and Phillips, D. V. 2006. Effect of crop rotation on take-all of wheat in double-cropping systems. Plant Dis. 90:1161-1166.

Take-all of wheat (Triticum aestivum), caused by Gaeumannomyces graminis var. tritici, became a serious problem with the widespread adoption of wheat:soybean double-cropping and minimum tillage farming systems in the southeastern United States during the past 30 years. A longterm crop rotation study was initiated in 1994 with 12 double-cropping sequences incorporating wheat, rye, or canola as the fall-planted crop and soybean or grain pearl millet as the summer crop. Cotton and fallow were included in some summer rotations during the last 2 years of the study. The purpose was to identify sustainable alternatives to the continuous wheat:soybean system that would provide acceptable management of take-all. G. graminis var. tritici cultured on autoclaved oats was incorporated into soil prior to planting the first season's crop. Take-all was severe in rotations with continuous wheat each year. Pearl millet was compatible with the cropping system but did not affect incidence or severity of take-all in a following wheat crop. Soybean or pearl millet had little effect on yield loss due to take-all in a subsequent wheat crop. A 1-year rotation with canola significantly reduced take-all incidence and severity. At the end of the second and third seasons, in those rotations where wheat followed 1 year of canola, wheat grain yield was the same as that in control plots that had little or no take-all. Two consecutive years of canola did not suppress take-all or improve wheat yields any more than a single year of canola between wheat crops. Seedling assays for take-all incidence and severity in growth chambers were conducted using soil collected twice each year near the end of each crop's growing season. Results were similar to those observed in the field. However, canola in the rotation had a greater effect in suppressing disease severity than disease incidence. Canola can be a valuable rotational crop for management of take-all in wheat in the southeastern United States.
\end{abstract}

Since the 1970s, autumn-planted wheat (Triticum aestivum) harvested in late May followed by soybean (Glycine max) became a favored double-cropping farming system in the southeastern United States $(3,12)$. As wheat production increased, take-all root rot, caused by Gaeumannomyces graminis var. tritici, became widespread, often resulting in more than $30 \%$ reduction in yield where wheat was grown for three or more consecutive years $(12,13)$. Prior to that time, when wheat acreage was much less, there were only infrequent reports of the disease (8). Crop rotation and avoidance of early planting are the only available methods to manage take-all in the region. Barley and rye (Secale cereale) are only mildly affected by the disease, but they maintain the fungus at a level that results in serious take-all damage when wheat is planted during the next season (13). Soybean in double-cropping systems with wheat maintains $G$. graminis var. tritici at a high level by interrupting take-all decline, and soil suppressiveness

Corresponding author: Barry M. Cunfer

E-mail: bcunfer@griffin.uga.edu

Accepted for publication 26 April 2006.

DOI: 10.1094/PD-90-1161

(C) 2006 The American Phytopathological Society does not develop as occurs in regions where continuous wheat monoculture is practiced (12). However, other crops, such as sorghum, may be suitable replacements for soybean as a summer crop. Sorghum reduced take-all damage in a following wheat crop in Georgia but did not eliminate $G$. graminis var. tritici after 3 years (14).

A project was begun to investigate alternative rotational crops in the wheat: soybean double-cropping system that would contribute to management of disease and insect pests and provide a sustainable farming system. The objective of this study was to find sustainable cropping systems that are alternative to continuous wheat:soybean for management of take-all. Therefore, canola (Brassica napus) and pearl millet (Pennisetum glaucum), new crops in the Southeast, were included, but sorghum and oats, previously known to suppress take-all, were not included. Twelve rotation sequences (Table 1) were established at the Southwest Branch Research and Extension Center at Plains, GA. Wheat is a significant component of double-cropping systems in this area of the Georgia coastal plain, and take-all is frequently encountered. Canola planted for grain or a rye cover crop, killed in early March, were alternatives to autumnplanted wheat. Grain pearl millet was an alternative to soybean during the summer cycle. Cotton and fallow were added to the summer crop sequence in some rotations in 1998 and 1999.

\section{MATERIALS AND METHODS}

Field plots. A 1.2-ha site with a Greenville sandy clay loam soil $(\mathrm{pH} 6.3$ and $<1 \%$ organic matter) at the Southwest Research and Education Center at Plains, GA, had been planted to alfalfa for 3 years. In June 1994, the field was deep-plowed and planted to soybean. The soybean crop was removed in October and the land was deep-tilled twice with a disk harrow prior to planting the first winter crop in the rotation sequence and before planting of winter crops in subsequent years. Forty-eight plots were laid out in a balanced randomized complete block with four replications. Each plot was $111.6 \mathrm{~m}^{2}(12.4 \times 9 \mathrm{~m})$ planted with a Hege plot planter (Wintersteiger-Hege, Colwich, KS). To maximize plot size within the site, within each repli-

Table 1. Crops and double-cropping rotation sequences evaluated during six seasons at the Southwest Research and Education Center, Plains, GA

\begin{tabular}{lcccccc}
\hline Rotation & $\mathbf{1 9 9 4 - 9 5}$ & $\mathbf{1 9 9 5 - 9 6}$ & $\mathbf{1 9 9 6 - 9 7}$ & $\mathbf{1 9 9 7 - 9 8}$ & $\mathbf{1 9 9 8 - 9 9}$ & $\mathbf{1 9 9 9 - 0 0}$ \\
\hline 1 & WS & WS & WS & WS & WS & W \\
2 & CS & CM & CS & CM & CS & W \\
3 & CS & WM & CM & WS & CCo & W \\
4 & CM & CS & WM & CCo & WS & W \\
5 & WS & CS & WM & CS & WS & W \\
6 & RS & CM & WS & FS & FS & W \\
7 & WS & CM & WS & WM & CCo & W \\
8 & CM & WM & WS & CCo & WCo & W \\
9 & WM & WM & WM & WCo & WCo & W \\
10 & WM & RS & CS & FCo & FCo & W \\
11 & CS & WM & CS & WS & CS & W \\
12 & RM & RS & WM & CS & CCo & W \\
\hline
\end{tabular}

${ }^{\mathrm{z}} \mathrm{C}=$ canola cv. Oscar, $\mathrm{Co}=$ cotton cv. Deltapine 51, $\mathrm{F}=$ fallow, $\mathrm{M}=$ pearl millet cv. HGM 100, $\mathrm{R}=$ rye cv. Wrens Abruzzi, S = soybean cv. Brim (1995), cv. Deltapine 105 (1996-99), W = wheat cv. Savannah (1994-98), cv. Roberts (1999). 
cate block, three sets of four plots each were grouped adjacent to one another. There was $12.2 \mathrm{~m}$ between each group of four plots within a block and $3 \mathrm{~m}$ between each of the four blocks. Twelve doublecropping rotation sequences were planted in early November (Table 1). Wheat (cv. Savannah), resistant to powdery mildew and leaf rust and moderately resistant to Stagonospora leaf and glume blotch, was planted in 1994 to 1998. These diseases were very low in all seasons and did not affect wheat yields. Wheat (cv. Roberts) was planted in 1999 because it is resistant to Hessian fly (Mayetiola destructor). Wheat and rye were planted in $20-\mathrm{cm}$ wide rows at a rate of 74 seeds per meter. Rye (cv. Wrens Abruzzi) was managed as a winter cover crop. Vegetative growth was removed in late February and the stubble killed with paraquat. Canola (cv. Oscar) was planted each year in late October in $18-\mathrm{cm}$-wide rows with $5.6 \mathrm{~kg}$ of seed per hectare. Crop management practices for pearl millet were reported previously (17).

Grassy weeds were controlled for wheat and rye each year by application of Hoelon 3EC (diclofop, 34\% active) in early January at 2.3 liters $\mathrm{ha}^{-1}$ beginning during the second season. For canola, Treflan 4EC (trifluralin, $43 \%$ active) was applied preplant at 1.2 liters $\mathrm{ha}^{-1}$ to control broadleaf weeds. Poast (sethoxydim, 18\% active) was applied 40 to 50 days after planting at 2.3 liters ha ${ }^{-1}+2.3$ liters ha ${ }^{-1}$ with crop oil to control grassy weeds. For soybean, Roundup (glyphosate, $41 \%$ active) was applied postemergence with a shielded sprayer. Wheat and canola were harvested in late May. Soybean, maturity group V (cv. Brim in 1995, cv. Deltapine 105 in other years), and pearl millet (cv. HGM 100) were planted with minimum tillage with a Monoseem air planter with appropriate plates in mid-June in 76-cm-wide rows at 26 seeds per meter. Pearl millet was harvested in early September and soybean was harvested in late October.

A culture of G. graminis var. tritici was isolated from wheat in a Georgia field with severe take-all. Preliminary inoculation tests we conducted demonstrated that it was highly aggressive to wheat. It was cultured on autoclaved oats according to the method described by Mathre (9). Airdried inoculum was ground in a hammer mill (Buffalo Manufacturing, model W8h) to pass through a $0.7-\mathrm{mm}$-diameter opening (9). Following deep tillage, the dry inoculum was spread by hand on the surface of each plot at a rate of $3.6 \mathrm{~g} \mathrm{~m}^{-2}$. A 2 $\times 12 \mathrm{~m}$ area on the right side of each plot was not inoculated to serve as a control. The inoculum was incorporated into the soil during light tillage to a depth of $15 \mathrm{~cm}$ just prior to planting of all crops on 8 and 9 November 1994. These infestations of $G$. graminis var. tritici were made to simulate continuous wheat that resulted in severe take-all. No additional inoculum was applied during the course of the study.

Field evaluations and yield components. The number of headed tillers per meter of row and those with whiteheads (disease incidence) were counted at five sites in each plot when plants were at decimal growth stage (GS) 75 (18) (milk stage). Wheat tillers and roots were removed from five locations (total $1.5 \mathrm{~m}$ of row) in each plot at GS 77 to 83 (late milk to early dough) in early May when take-all symptoms were most severe. Roots, crowns, and stem bases were rated for take-all severity by examination of typical runner hyphae and black discoloration in water against a white background after thorough wetting using a modification of the 0 to 4 scale $(15)$ in which $0=$ no disease, $1=$ up to $25 \%$ of the root system with runner hyphae and discoloration, $2=$ 26 to $50 \%$ of the roots affected with crown rot and less than $10 \%$ of the stem base blackened, $3=51$ to $75 \%$ of the root affected, crown rot, and 11 to $50 \%$ of the stem base blackened with symptoms extending up the stem, and $4=>75 \%$ of the roots affected, crown rot, and $>75 \%$ of the stem blackened with symptoms extending several centimeters up the stem. Most tillers in categories 3 and 4 were prematurely killed. Isolations were made from selected crowns with take-all symptoms onto modified SM-GGT3 agar each year to confirm the presence of G. graminis var. tritici (9). Grain yield components, yield, test weight $\left(\mathrm{kg} \mathrm{h}^{-1}\right)$, and 1,000 kernel weight, were determined from grain harvested from a 93 $\mathrm{m}^{2}$ area of the inoculated portion of each plot during the first 2 years and from a 37 $\mathrm{m}^{2}$ area in subsequent years. Control samples for tillers were harvested from eight arbitrarily selected sites within the noninfested areas of plots. Grain was harvested from the $24 \mathrm{~m}^{2}$ noninfested portion of each plot. Grain yield and test weight values were adjusted to $13 \%$ moisture.

Seedling assays. In mid-April (1995 to 1998) and again in early September, near the end of growth of the summer crop, soil and wheat root fragments were collected at four sites, each $20 \mathrm{~cm}^{2}$ and $20 \mathrm{~cm}$ deep, within the infested area of each plot. Collection sites were selected by using random numbers from 1 to 10 and walking the designated number of paces between sites diagonally across each plot beginning at different corners for each plot. During 1999 and 2000, samples were collected only in April. Similar samples were collected from the noninfested area of each plot and from the noninfested unplanted areas of the field. Soil samples were airdried and homogenized with a soil shredder (Lindig Company). Eight 9-cm plastic pots were filled with soil from each field sample to within $2 \mathrm{~cm}$ of the top. Twelve seeds of wheat (cv. Savannah) were placed on the soil surface in each pot and covered with a 1-cm layer of washed white sand with two pots of each sample constituting one replicate. There were four replicates (24 seeds) per soil sample. Two replicates of each soil sample were placed in two identical growth chambers (Conviron Corp., Winnipeg, Canada) at 16 to $17^{\circ} \mathrm{C}$ with a 12-h photoperiod supplied by coolwhite fluorescent and incandescent lamps. The pots were watered three times per week and fertilized with ammonium nitrate (10 $\left.\mathrm{g} \mathrm{liter}^{-1}\right)$ every 10 days. The seedlings were grown for 10 to 12 weeks until takeall symptoms on roots and stem bases were moderate to severe in the continuous wheat treatments (rotations 1 and 9, Table 1). Soil was washed from seedlings, and they were air-dried and stored 3 to 4 weeks until observation. Seedlings were rated for takeall incidence and severity as described for field-collected tillers. A minimum of 80 seedlings per rotation were examined each time. The results were compared with disease ratings from the field.

Statistics. All data were analyzed using SAS PROC GLM (SAS Institute, Research Triangle, NC). Percentage of take-all incidence data in all experiments were arcsine transformed to reduce errors in estimation of variance. Incidence data presented in the tables are nontransformed values. Following significant $F$ tests, means separation tests using the protected LSD were used for yield and disease component data.

Take-all incidence and severity from the growth chamber seedling tests were examined by single degree-of-freedom contrasts on specific two-crop segments of the rotation sequences during the 6-year period of the study. For example, take-all incidence of wheat seedlings planted in soil collected in April near the end of a wheat crop (first crop) was compared with take-all incidence of seedlings grown in soil collected the following September near the end of the summer soybean crop (second crop). Four to 12 comparisons were available for analysis among six rotation sequences. Comparisons are numbered in the order of their occurrence in the rotation sequences in Table 1.

\section{RESULTS}

Field evaluations and yield components. Take-all inoculation produced severe infection and damage to wheat in the first season (1995) and in all subsequent rotations with continuous wheat. Production of typical hyphae and black pigment in modified SM-GGT3 agar confirmed $G$. graminis var. tritici from symptomatic crowns of mature wheat collected each year for disease incidence and severity ratings (9). After 3 years, there were no differences in wheat yield or disease incidence and severity between the two continuous wheat treatments with either continuous soybean (rotation 1) or continuous pearl millet (rotation 9) as the summer crop (Tables 2 to 4). Wheat grain test weight and 1,000 kernel weight were sig- 
nificantly higher in the continuous wheat: pearl millet rotation than in continuous wheat:soybean in 1996 but not in 1997 or 1998. However, pearl millet did not reduce take-all incidence or severity and had no effect on grain yield in either season compared with the control (Tables 2 to 4 ). Therefore, the summer crop was not considered in comparisons between rotations.

By 1996 (season 2), rotations 3 and 8, which had 1 year of canola before wheat, and the noninoculated control had at least twice as many tillers per meter of row as the two rotations ( 1 and 9 ) with continuous wheat (Table 2). Take-all incidence also declined significantly in rotations 3 and 8 with canola the previous year compared with continuous wheat (rotations 1 and 9). Disease severity rating was 3.6 in continuous wheat:soybean but less than 1.5 in rotations with canola.

Results for 1997 (season 3) were similar (Table 3). Number of tillers was significantly greater in the noninoculated control and in rotations $4,5,6$, and 7 with canola 1 year prior to wheat compared with continuous wheat (rotations 1 and 9) and 2 years of wheat following canola (rotation 8). Take-all incidence and severity were significantly lower than continuous wheat in rotations 4 and 5 with canola the previous year when soybean was the summer crop. Likewise, disease severity was significantly lower than continuous wheat in rotations 6 and 7 with canola the previous year when pearl millet was the summer crop. However, neither soybean nor pearl millet as the summer crop following canola had any effect on wheat yield or other yield components. Coefficients of variation were high for disease incidence (22.5) and severity (28.2) but were $<12$ for all other parameters evaluated. When compared over the two seasons, all rotations with at least 1 year with canola between wheat crops resulted in a 28 to $57 \%$ decrease in disease incidence and a significant reduction in disease severity on roots and crowns compared with continuous wheat (Tables 2 and 3).

Wheat grain yield was severely reduced because of take-all in the rotations with continuous wheat in all seasons. Yields in the rotations with canola the previous year were significantly greater than yields in the continuous wheat and similar to yields in the noninoculated controls where very little take-all occurred (Tables 2 to 4). However, wheat yield declined to the same level as continuous wheat after 2 years of wheat following canola (rotation 8, Table 3 ). Test weight in rotations with canola and the control was the same both years and significantly higher than continuous wheat (Tables 2 and 3). Thousand kernel weight was greater in treatments following canola than those with continuous wheat in 1996 only (Table 2).

Results for yield components and disease parameters were similar in 1998 al- though not as clear-cut as in the previous two seasons (Table 4). The influence of canola in the rotation to maintain grain yield and suppress take-all was evident in all six parameters evaluated. In 1996 to

1998, take-all incidence (\% whiteheads) following canola the previous season was often as high as $50 \%$ or more (Tables 2 to 4). However, disease severity rating on the roots of tillers with signs of $G$. graminis

Table 2. Yield components of cv. Savannah wheat and take-all incidence and severity response to crop rotation, Plains, GA 1995-96

\begin{tabular}{|c|c|c|c|c|c|c|}
\hline Rotation & $\begin{array}{c}\text { Yield } \\
\left(\mathrm{kg} \mathrm{ha}^{-1}\right)\end{array}$ & $\begin{array}{l}\text { Test weight } \\
\quad\left(\mathrm{kg} \mathrm{hl}^{-1}\right)\end{array}$ & $\begin{array}{c}1,000 \\
\text { kernel } \\
\text { weight }(\mathrm{g})\end{array}$ & $\begin{array}{l}\text { No. tillers } \\
\mathbf{m}^{-1}\end{array}$ & $\begin{array}{c}\text { Disease } \\
\text { incidence } \\
\text { (\% whiteheads) }\end{array}$ & $\begin{array}{c}\text { Disease } \\
\text { severity } \\
(0-4)^{x}\end{array}$ \\
\hline $1 \mathrm{WSW}^{\mathrm{y}}$ & $262 b^{z}$ & $52.7 \mathrm{c}$ & $15.1 \mathrm{c}$ & $23 \mathrm{~b}$ & $100 \mathrm{a}$ & $3.6 \mathrm{a}$ \\
\hline $3 \mathrm{CSW}$ & $3,148 \mathrm{a}$ & $68.8 \mathrm{a}$ & $27.6 \mathrm{a}$ & $61 \mathrm{a}$ & $72 a b$ & $1.4 \mathrm{bc}$ \\
\hline 8 CMW & $2,812 \mathrm{a}$ & $69.5 \mathrm{a}$ & $29.2 \mathrm{a}$ & $54 \mathrm{a}$ & $54 \mathrm{~b}$ & $1.2 \mathrm{bc}$ \\
\hline 9 WMW & $538 \mathrm{~b}$ & $58.6 \mathrm{~b}$ & $19.3 \mathrm{~b}$ & $28 \mathrm{~b}$ & $99 \mathrm{a}$ & $2.6 \mathrm{ab}$ \\
\hline Control & $3,107 \mathrm{a}$ & $69.4 \mathrm{a}$ & $28.5 \mathrm{a}$ & $48 \mathrm{a}$ & $11 \mathrm{c}$ & $0.1 \mathrm{~d}$ \\
\hline
\end{tabular}

${ }^{\mathrm{x}} 0=$ no disease, $1=$ up to $25 \%$ of the root system with runner hyphae and discoloration, $2=26$ to $50 \%$ of the roots affected with crown rot, and less than $10 \%$ of the stem base blackened, $3=51$ to $75 \%$ of the root affected, crown rot, and 11 to $50 \%$ of the stem base blackened with symptoms extending up the stem, and $4=>75 \%$ of the roots affected, crown rot, and $>75 \%$ of the stem blackened with symptoms extending several $\mathrm{cm}$ up the stem.

y $\mathrm{C}=$ canola, $\mathrm{M}=$ pearl millet, $\mathrm{S}=$ soybean, and $\mathrm{W}=$ wheat. Canola and wheat are fall planted crops; pearl millet and soybean are summer crops.

${ }^{\mathrm{z}}$ Means in columns followed by the same letter are not significantly different according to protected $\operatorname{LSD}(P=0.05)$.

Table 3. Yield components of cv. Savannah wheat and take-all incidence and severity in response to crop rotation, Plains, GA 1996-97

\begin{tabular}{|c|c|c|c|c|c|c|}
\hline Rotation & $\begin{array}{c}\text { Yield } \\
\left(\mathrm{kg} \mathrm{ha}^{-1}\right)\end{array}$ & $\begin{array}{l}\text { Test weight } \\
\quad\left(\mathrm{kg} \mathrm{hl}^{-1}\right)\end{array}$ & $\begin{array}{c}1,000 \\
\text { kernel } \\
\text { weight }(\mathrm{g})\end{array}$ & $\begin{array}{l}\text { No. } \\
\text { tillers } \mathbf{m}^{-1}\end{array}$ & $\begin{array}{c}\text { Disease } \\
\text { incidence } \\
\text { (\% whiteheads) }\end{array}$ & $\begin{array}{c}\text { Disease } \\
\text { severity }^{\mathrm{W}} \\
(0-4)\end{array}$ \\
\hline 1 WSWSW $^{\mathrm{x}}$ & $1,984 b^{y}$ & $75.4 \mathrm{~d}$ & $33.5 \mathrm{ab}$ & $49 \mathrm{~b}$ & $81 \mathrm{a}$ & $1.7 \mathrm{a}$ \\
\hline 4 CMCSW & $3,033 \mathrm{a}$ & $77.0 \mathrm{abc}$ & $34.1 \mathrm{ab}$ & $68 \mathrm{a}$ & $50 \mathrm{~d}$ & $0.6 \mathrm{~cd}$ \\
\hline 5 WSCSW & $3,087 \mathrm{a}$ & $77.2 \mathrm{ab}$ & $32.3 \mathrm{~b}$ & $74 \mathrm{a}$ & $49 \mathrm{~d}$ & $0.5 \mathrm{~d}$ \\
\hline 6 RSCMW & $2,993 \mathrm{a}$ & $77.6 \mathrm{ab}$ & $35.7 \mathrm{a}$ & $70 \mathrm{a}$ & 64 a-d & $0.9 \mathrm{bcd}$ \\
\hline 7 WSCMW & $2,845 \mathrm{a}$ & $77.6 \mathrm{ab}$ & $35.8 \mathrm{a}$ & $69 \mathrm{a}$ & $62 \mathrm{a}-\mathrm{d}$ & $0.8 \mathrm{bcd}$ \\
\hline 8 CMWMW & $1,823 \mathrm{~b}$ & $76.3 \mathrm{bcd}$ & $34.3 \mathrm{ab}$ & $49 \mathrm{~b}$ & $63 a-d$ & $1.1 \mathrm{bc}$ \\
\hline 9 WMWMW & $1,910 \mathrm{~b}$ & $75.8 \mathrm{bcd}$ & $34.2 \mathrm{ab}$ & $54 \mathrm{~b}$ & $78 \mathrm{abc}$ & $1.2 \mathrm{ab}$ \\
\hline 12 RMRSW & $2,764 \mathrm{a}$ & $75.6 \mathrm{~d}$ & $33.1 \mathrm{ab}$ & $69 a$ & $80 \mathrm{ab}$ & $1.2 \mathrm{ab}$ \\
\hline Control $^{\mathrm{z}}$ & $3,084 \mathrm{a}$ & $77.7 \mathrm{a}$ & $35.2 \mathrm{a}$ & $72 \mathrm{a}$ & $59 \mathrm{~cd}$ & $0.6 \mathrm{~cd}$ \\
\hline
\end{tabular}

${ }^{\mathrm{w}} 0=$ no disease, $1=$ up to $25 \%$ of the root system with runner hyphae and discoloration, $2=26$ to $50 \%$ of the roots affected with crown rot, and less than $10 \%$ of the stem base blackened, $3=51$ to $75 \%$ of the root affected, crown rot, and 11 to $50 \%$ of the stem base blackened with symptoms extending up the stem, and $4=>75 \%$ of the roots affected, crown rot, and $>75 \%$ of the stem blackened with symptoms extending several $\mathrm{cm}$ up the stem.

${ }^{x} \mathrm{C}=$ canola, $\mathrm{M}=$ pearl millet, $\mathrm{R}=$ rye, $\mathrm{S}=$ soybean, and $\mathrm{W}=$ wheat. Canola and wheat are fallplanted crops; pearl millet and soybean are summer crops.

y Means in columns followed by the same letter are not significantly different according to protected $\operatorname{LSD}(P=0.05)$.

${ }^{\mathrm{z}}$ Harvested from noninoculated portion of plots in rotations 4 and 6.

Table 4. Yield components and disease incidence and severity for cv. Savannah wheat in response to crop rotation and take-all root rot, Plains, GA 1997-98

\begin{tabular}{|c|c|c|c|c|c|c|}
\hline Rotation & $\begin{array}{c}\text { Yield } \\
\left(\mathrm{kg} \mathrm{ha}^{-1}\right)\end{array}$ & $\begin{array}{c}\text { Test } \\
\text { weight } \\
\left(\mathrm{kg} \mathrm{hl}^{-1}\right)\end{array}$ & $\begin{array}{c}1,000 \\
\text { kernel } \\
\text { weight (g) }\end{array}$ & $\begin{array}{l}\text { No. } \\
\text { tillers } \text { m }^{-1}\end{array}$ & $\begin{array}{c}\text { Disease } \\
\text { incidence } \\
\text { (\% whiteheads) }\end{array}$ & $\begin{array}{c}\text { Disease } \\
\text { severity }^{\mathrm{x}} \\
(0-4)\end{array}$ \\
\hline 1 WSWSWSWy & $2,814 \mathrm{~b}^{\mathrm{z}}$ & $73.4 \mathrm{~b}$ & $28.2 \mathrm{abc}$ & $76 \mathrm{bc}$ & $82 \mathrm{a}$ & $1.2 \mathrm{a}$ \\
\hline 3 CSWMCMW & $3,427 \mathrm{ab}$ & $72.8 \mathrm{~b}$ & $30.4 \mathrm{a}$ & $82 \mathrm{ab}$ & $24 \mathrm{c}$ & $0.2 \mathrm{~b}$ \\
\hline 7 WSCMWSW & $2,808 \mathrm{bc}$ & $72.6 \mathrm{~b}$ & $27.8 \mathrm{bc}$ & $79 a b c$ & $62 \mathrm{ab}$ & $1.3 \mathrm{a}$ \\
\hline 9 WMWMWMW & $2,903 \mathrm{~b}$ & $74.2 \mathrm{ab}$ & $29.0 \mathrm{abc}$ & $72 \mathrm{c}$ & $59 \mathrm{ab}$ & $0.8 \mathrm{ab}$ \\
\hline 11 CSWMCSW & $3,423 \mathrm{ab}$ & $75.2 \mathrm{ab}$ & $29.6 \mathrm{ab}$ & $88 \mathrm{a}$ & $47 \mathrm{~b}$ & $0.7 \mathrm{ab}$ \\
\hline Control & $3,936 \mathrm{a}$ & $76.4 \mathrm{a}$ & $30.2 \mathrm{a}$ & $85 \mathrm{a}$ & $34 \mathrm{c}$ & $0.3 \mathrm{c}$ \\
\hline
\end{tabular}

${ }^{x} 0=$ no disease, $1=$ up to $25 \%$ of the root system with runner hyphae and discoloration, $2=26$ to $50 \%$ of the roots affected with crown rot, and less than $10 \%$ of the stem base blackened, $3=51$ to $75 \%$ of the root affected, crown rot, and 11 to $50 \%$ of the stem base blackened with symptoms extending up the stem, and $4=>75 \%$ of the roots affected, crown rot, and $>75 \%$ of the stem blackened with symptoms extending several $\mathrm{cm}$ up the stem.

${ }^{y} \mathrm{C}=$ canola, $\mathrm{M}=$ pearl millet, $\mathrm{S}=$ soybean, and $\mathrm{W}=$ wheat. Canola and wheat are fall-planted crops; pearl millet and soybean are summer crops.

${ }^{\mathrm{z}}$ Means in columns followed by the same letter are not significantly different according to protected $\operatorname{LSD}(P=0.05)$. 
var. tritici was almost always a 1. In 1997, rotation 12 with two previous years of rye cover crop had tillers per meter of row and grain yield that were the same as the control and significantly greater than the continuous wheat rotations (1 and 9). Conversely, test weight, 1,000 kernel weight, and disease incidence and severity did not differ from continuous wheat (Table 3 ).

Seedling assays. Observation of typical runner hyphae of G. graminis var. tritici on seedling roots and isolation of hyphae surrounded by black pigment in modified SM-GGT 3 medium confirmed $G$. graminis var. tritici at each sampling time. The following comparisons are significant at $P=0.05$ unless otherwise stated. Additional comparisons were significant at $P=$ 0.10 (Table 5). In comparisons of wheat followed by soybean, disease incidence did not change significantly in five of the seven available comparisons, but disease severity decreased following soybean in three of seven comparisons. When wheat followed soybean, take-all incidence increased significantly $(P=0.10)$ in four of six comparisons, and take-all severity increased significantly in all six comparisons.

Disease incidence in seedlings decreased moderately when pearl millet followed wheat with a significant decline in only two of six comparisons (Table 5). Disease severity was significantly lower after pearl millet in three of six comparisons. Conversely, when wheat followed pearl millet, take-all incidence increased significantly in two of four comparisons and take-all severity increased significantly in all four comparisons.

In comparisons of canola following wheat, average take-all incidence declined from $83 \%$ after wheat to $54 \%$ after canola the next season, although the decline was significant only at $P=0.10$ in only three of nine comparisons (Table 5). Disease severity declined significantly in six of eight comparisons. Conversely, when wheat followed canola, disease incidence increased significantly in three of 12 comparisons and take-all severity increased in six of 12 comparisons.

The seedling assay results paralleled the field data in that take-all incidence and severity declined substantially following canola. Incidence and severity declined only moderately after pearl millet and soybean.

Table 5. Single degree-of-freedom contrasts for take-all incidence and severity in tests with wheat seedlings grown in soil from two consecutive crops in six rotation sequences during the 6 years of the study

\begin{tabular}{|c|c|c|c|c|c|c|c|}
\hline \multirow[b]{2}{*}{ Rotation sequence } & \multirow[b]{2}{*}{ Comparison } & \multicolumn{3}{|c|}{ Disease incidence (\%) } & \multicolumn{3}{|c|}{ Disease severity ${ }^{\mathrm{y}}(0-4)$} \\
\hline & & 1st crop ${ }^{z}$ & 2nd crop & $P$ & 1st crop & 2nd crop & $P$ \\
\hline \multirow[t]{7}{*}{ Wheat-soybean } & 1 & 87 & 100 & NS & 1.6 & 1.5 & NS \\
\hline & 2 & 100 & 39 & $<0.01$ & 1.4 & 0.4 & 0.02 \\
\hline & 3 & 100 & 86 & NS & 1.9 & 1.7 & NS \\
\hline & 4 & 76 & 58 & NS & 1.6 & 0.6 & 0.01 \\
\hline & 5 & 99 & 98 & NS & 1.7 & 2.0 & NS \\
\hline & 6 & 60 & 63 & NS & 1.6 & 0.7 & 0.10 \\
\hline & 7 & 100 & 58 & 0.06 & 3.0 & 0.8 & $<0.01$ \\
\hline \multirow[t]{6}{*}{ Soybean-wheat } & 1 & 100 & 100 & NS & 1.5 & 3.3 & $<0.01$ \\
\hline & 2 & 39 & 95 & $<0.01$ & 0.4 & 2.0 & $<0.01$ \\
\hline & 3 & 26 & 80 & 0.08 & 0.3 & 1.7 & 0.02 \\
\hline & 4 & 63 & 90 & NS & 0.7 & 2.2 & $<0.01$ \\
\hline & 5 & 22 & 86 & 0.01 & 0.2 & 1.9 & $<0.01$ \\
\hline & 6 & 49 & 96 & 0.04 & 0.6 & 2.6 & $<0.01$ \\
\hline \multirow[t]{9}{*}{ Wheat-canola } & 1 & 80 & 26 & 0.08 & 1.7 & 0.4 & 0.03 \\
\hline & 2 & 88 & 53 & NS & 2.7 & 0.8 & $<0.01$ \\
\hline & 3 & 30 & 52 & NS & 0.6 & 0.5 & NS \\
\hline & 4 & 100 & 80 & NS & 1.9 & 1.1 & NS \\
\hline & 5 & 73 & 63 & NS & 2.2 & 0.7 & 0.01 \\
\hline & 6 & 99 & 65 & NS & 1.7 & 0.7 & 0.05 \\
\hline & 7 & 90 & 48 & 0.07 & 2.2 & 0.6 & $<0.01$ \\
\hline & 8 & 100 & 44 & $<0.01$ & 3.0 & 0.4 & $<0.01$ \\
\hline & 9 & 86 & 58 & NS & 1.9 & 1.2 & NS \\
\hline \multirow[t]{12}{*}{ Canola-wheat } & 1 & 24 & 80 & 0.07 & 0.4 & 1.7 & 0.04 \\
\hline & 2 & 26 & 88 & 0.01 & 0.4 & 2.6 & $<0.01$ \\
\hline & 3 & 41 & 30 & NS & 0.4 & 0.6 & NS \\
\hline & 4 & 52 & 37 & NS & 0.6 & 0.7 & NS \\
\hline & 5 & 80 & 73 & NS & 1.1 & 2.2 & 0.06 \\
\hline & 6 & 63 & 58 & NS & 0.7 & 1.4 & NS \\
\hline & 7 & 31 & 76 & 0.02 & 0.3 & 1.6 & $<0.01$ \\
\hline & 8 & 65 & 60 & NS & 0.7 & 1.6 & 0.09 \\
\hline & 9 & 37 & 75 & 0.09 & 0.5 & 1.5 & 0.02 \\
\hline & 10 & 44 & 42 & NS & 0.4 & 0.4 & NS \\
\hline & 11 & 18 & 86 & $<0.01$ & 0.2 & 1.9 & 0.01 \\
\hline & 12 & 58 & 96 & 0.09 & 1.2 & 2.6 & 0.01 \\
\hline \multirow[t]{6}{*}{ Wheat-pearl millet } & 1 & 30 & 45 & NS & 0.6 & 0.6 & NS \\
\hline & 2 & 73 & 38 & 0.06 & 2.2 & 0.4 & 0.05 \\
\hline & 3 & 99 & 100 & NS & 1.9 & 1.9 & NS \\
\hline & 4 & 95 & 43 & $<0.01$ & 1.3 & 0.4 & 0.01 \\
\hline & 5 & 77 & 90 & NS & 1.3 & 1.6 & NS \\
\hline & 6 & 100 & 64 & 0.05 & 3.0 & 0.7 & $<0.01$ \\
\hline \multirow[t]{4}{*}{ Pearl millet-wheat } & 1 & 53 & 85 & NS & 0.5 & 2.7 & $<0.01$ \\
\hline & 2 & 37 & 75 & 0.05 & 0.6 & 1.5 & 0.04 \\
\hline & 3 & 100 & 100 & NS & 1.9 & 3.2 & $<0.01$ \\
\hline & 4 & 43 & 96 & 0.01 & 0.4 & 2.2 & $<0.01$ \\
\hline
\end{tabular}

y $0=$ no disease, $1=$ up to $25 \%$ of the root system with runner hyphae and discoloration, $2=26$ to $50 \%$ of the roots affected with crown rot, and less than $10 \%$ of the stem base blackened, $3=51$ to $75 \%$ of the root affected, crown rot, and 11 to $50 \%$ of the stem base blackened with symptoms extending up the stem, and $4=>75 \%$ of the roots affected, crown rot, and $>75 \%$ of the stem blackened with symptoms extending several cm up the stem.

${ }^{\mathrm{z}}$ First and second crop refers to sequence of crops in each pair. In the wheat-soybean sequence, wheat is the first crop and soybean is the second crop. Comparisons are numbered in order of their occurrence in the rotation sequences in Table 1. 
Single degree-of-freedom comparisons over the last 3 years of the study were made to examine the effect of winter canola and fallow on take-all incidence and severity following wheat or canola (Table 6). Take-all incidence and severity were substantially greater in the first year after wheat (rotations 6 and 12) than canola (rotations 2 and 10). Incidence and severity after wheat declined significantly following both fallow (rotation 6) and canola (rotation 12) in the second year with a further significant decline after canola in the third year. However, take-all incidence and severity were not significantly different between canola and fallow following wheat (rotations 6 and 12, respectively) in the second and third years.

In contrast, take-all incidence and severity were low in rotations 2 and 10 with canola in the first year and did not change significantly after a second or third year of winter fallow or canola (Table 6). Disease incidence and severity were not significantly different when canola was followed by either fallow or canola for 2 years. Finally, take-all incidence in the last year ranged from 3 to $32 \%$ but was not significantly different between rotations regardless of whether wheat or canola was grown in the first year and was followed by winter fallow or canola. Likewise, disease severity ranged from $<0.1$ to 0.4 and was not different between these rotations in the third year.

\section{DISCUSSION}

Take-all was not completely suppressed by any crop rotation sequence and remained high in continuous wheat:soybean rotations as shown in previous studies in the southeastern United States (11-14). Take-all incidence and severity declined somewhat following soybean and millet, indicating a decline in inoculum of $G$. graminis var. tritici, but these crops did not affect grain yield or other yield components in the following wheat crop. A 1-year rotation with canola is sufficient to control take-all in a double-cropping system. No additional yield improvement resulted when canola was planted two consecutive years between wheat crops. Therefore, $G$. graminis var. tritici continued to be present at a level below economic impact after a year of canola, and the effect of reduction in take-all was limited to one season of wheat after canola.

The rapid reduction in take-all severity with a resultant recovery in grain yield equal to the noninfected control after 1 year of canola was unexpected. Take-all was severe as evidenced by the low yields, especially in 1996 in the continuous wheat treatments. The reduction in take-all severity could have been due to the absence of a susceptible host between wheat crops, such as occurs with oats. However, in vitro studies have shown that glucosinolate compounds from decaying canola tissue significantly suppress growth of $G$. graminis var. tritici $(1,2)$. Whether the concentration of these compounds in the field is sufficient to cause this suppression is not known. If glucosinolates from canola contribute to inoculum reduction, this may explain in part the precipitous reduction of take-all following canola. The influence of canola on the population of soilborne antagonists of $G$. graminis var. tritici is also unknown.

Regardless of the crop rotation sequences, single degree-of-freedom contrasts showed that take-all severity decreased more than incidence following canola and increased more following wheat (Tables 5 and 6). Declines in incidence and disease severity were the same following soybean and pearl millet and reflected the results from yield and field data on incidence and severity. One- or 2year rotations with canola caused signifi- cant reductions in take-all incidence but did not eliminate $G$. graminis var. tritici. Lower inoculum levels may result in more infections beginning later in the season that maintain a higher incidence level but result in lower disease severity that season. The canola effect in reducing inoculum is similar to that of the wide range of grassy weed species including ryegrass (Lolium perenne) and Bromus spp. in the southeastern United States that express no visible symptoms (low severity) but maintain $G$. graminis var. tritici (9). Grassy weeds, especially ryegrass, were controlled in the field plots but were not eliminated. Therefore, they maintained a background level of $G$. graminis var. tritici inoculum.

Canola following wheat suppressed take-all symptoms and resulted in significant yield increases in a subsequent wheat crop in a monoculture cropping system in Australia (1). Canola was effective in controlling take-all, whereas soil application of a fungicide, chloride, or microbial antagonists failed (4). Some of the yield response in Australia was attributed to better water infiltration in soil following brassica crops, but a major effect was considered to be due to a "biofumigation" effect on $G$. graminis var. tritici from release of isothiocyanates during the breakdown of brassica residues (6). Similar to our results, the brassica crops did not eliminate $G$. graminis var. tritici as seen by an increase in take-all damage two or more years after brassica (4). Brassica residues also have been shown to suppress soilborne pathogens on other crops $(10,16,19)$.

Rothrock and Langdale (14) reported an $8.5 \%$ yield increase and a decline in takeall damage with sorghum as the summer crop in place of soybean after 3 years in a continuous wheat:soybean, doublecropping system in Georgia. Sorghum as a summer crop was equal to fallow in reducing take-all damage and improving grain

Table 6. Single degree-of-freedom contrasts among three pairs of rotation sequences for take-all incidence and severity in wheat seedling tests

\begin{tabular}{|c|c|c|c|c|c|c|c|c|c|c|}
\hline Rotation & & & isease in & nce $(\%)$ & & & Dis & severity & & \\
\hline 6 & $\begin{array}{l}\text { Wheat }{ }^{y} \\
76\end{array}$ & $(0.02)^{\mathrm{z}}$ & $\begin{array}{l}\text { Fallow } \\
33\end{array}$ & & $\begin{array}{l}\text { Fallow } \\
17\end{array}$ & $\begin{array}{l}\text { Wheat } \\
1.6\end{array}$ & $(0.003)$ & $\begin{array}{l}\text { Fallow } \\
0.3\end{array}$ & & $\begin{array}{l}\text { Fallow } \\
0.2\end{array}$ \\
\hline 10 & $\begin{array}{l}\text { Canola } \\
30 \\
(0.04)\end{array}$ & & $\begin{array}{l}\text { Fallow } \\
33\end{array}$ & & $\begin{array}{l}\text { Fallow } \\
32\end{array}$ & $\begin{array}{l}\text { Canola } \\
0.3\end{array}$ & & $\begin{array}{l}\text { Fallow } \\
0.4\end{array}$ & & $\begin{array}{l}\text { Fallow } \\
0.4\end{array}$ \\
\hline 2 & $\begin{array}{l}\text { Canola } \\
22\end{array}$ & & $\begin{array}{l}\text { Canola } \\
18\end{array}$ & & $\begin{array}{l}\text { Canola } \\
15\end{array}$ & $\begin{array}{l}\text { Canola } \\
0.4\end{array}$ & & $\begin{array}{l}\text { Canola } \\
0.2\end{array}$ & & $\begin{array}{l}\text { Canola } \\
0.2\end{array}$ \\
\hline 12 & $\begin{array}{l}\text { Wheat } \\
100 \\
(0.001)\end{array}$ & $(0.03)$ & $\begin{array}{l}\text { Canola } \\
57 \\
(0.03)\end{array}$ & $(0.08)$ & $\begin{array}{l}\text { Canola } \\
3\end{array}$ & $\begin{array}{l}\text { Wheat } \\
3.0 \\
(0.001)\end{array}$ & $(0.001)$ & $\begin{array}{l}\text { Canola } \\
0.9\end{array}$ & $(0.08)$ & $\begin{array}{l}\text { Canola } \\
<0.1\end{array}$ \\
\hline 2 & $\begin{array}{l}\text { Canola } \\
22\end{array}$ & & $\begin{array}{l}\text { Canola } \\
18\end{array}$ & & $\begin{array}{l}\text { Canola } \\
15\end{array}$ & $\begin{array}{l}\text { Canola } \\
0.4\end{array}$ & & $\begin{array}{l}\text { Canola } \\
0.2\end{array}$ & & $\begin{array}{l}\text { Canola } \\
0.2\end{array}$ \\
\hline 10 & $\begin{array}{l}\text { Canola } \\
30\end{array}$ & & $\begin{array}{l}\text { Fallow } \\
33\end{array}$ & & $\begin{array}{l}\text { Fallow } \\
32\end{array}$ & $\begin{array}{l}\text { Canola } \\
0.3\end{array}$ & & $\begin{array}{l}\text { Fallow } \\
0.4\end{array}$ & & $\begin{array}{l}\text { Fallow } \\
0.4\end{array}$ \\
\hline
\end{tabular}

${ }^{\mathrm{x}} 0=$ no disease, $1=$ up to $25 \%$ of the root system with runner hyphae and discoloration, $2=26$ to $50 \%$ of the roots affected with crown rot, and less than $10 \%$ of the stem base blackened, $3=51$ to $75 \%$ of the root affected, crown rot, and 11 to $50 \%$ of the stem base blackened with symptoms extending up the stem, and $4=>75 \%$ of the roots affected, crown rot, and $>75 \%$ of the stem blackened with symptoms extending several $\mathrm{cm}$ up the stem.

y Sampling dates (left to right) for the three crops were 1 April 1997, 1 May 1998, and 20 April 1999.

${ }^{\mathrm{z}} P$ values are noted in parentheses; values on the horizontal indicate significant differences between crops within a rotation. Values on the vertical indicate significant differences between crops between rotations. Absence of $P$ values between comparisons indicates these were not significant. 
yield. Pearl millet for grain is similar in production practices to sorghum and fits well into the rotation as a short-season drought-tolerant summer crop $(7,17)$. However, unlike sorghum, pearl millet had no beneficial effect on take-all when planted in place of soybean. Consequently, sorghum is the only summer crop in double-cropping rotations in the southeastern United States known to suppress take-all (14).

Two years of a rye cover crop resulted in tiller counts and yield the same as the control, but take-all incidence and severity were the same as in continuous wheat. A rye cover crop in the rotation still maintains $G$. graminis var. tritici at a significant level. Therefore, its use for long-term management of take-all is questionable.

Although a fallow period between wheat crops is well-known as a useful management tool for G. graminis var. tritici, profit margins are low for most field crops in the southeastern United States. Therefore, double-cropping without fallow periods is needed. Canola as a winter crop reduced take-all damage to that of the noninoculated control and was similar to fallow in reducing take-all incidence and severity. Canola has the potential to be a more profitable winter crop than rye as a cover crop, oats for forage or grain, or winter fallow. Like rye or oats, canola can also reduce soil erosion during the winter. A single year of canola fits well with current crop rotation recommendations for the southeastern United States to avoid Phoma black leg and Sclerotinia stem rot damage to canola (5).
ACKNOWLEDGMENTS

This research was funded in part by the Southern Region USDA Sustainable Agriculture Research and Education grant L94-57 and State and Hatch funds provided to the Georgia Agricultural Experiment Stations. We thank John Youmans, Howell Fowler, Robert Slaughter, and David Spradlin for technical assistance, Ronny Pines and Stanley Jones for assistance with management of field plots, and Jerry Davis for assistance with statistical analyses.

\section{LITERATURE CITED}

1. Angus, J. F., Gardner, P. A., Kirkegaard, J. A., and Desmarchlier, J. M. 1994. Biofumigation: isothiocyanates released from Brassica roots inhibit growth of the take-all fungus. Plant Soil 162:107-112.

2. Angus, J. F., van Herwaade, A. F., and Howe, G. N. 1993. Productivity and break-crop effects of winter growing oilseeds. Aust. J. Exp. Agric. 31:669-677.

3. Cunfer, B. M., and Rothrock, C. S. 1994. The influence of conservation and double cropping practices on diseases of wheat in Georgia. Ga. Agric. Exp. Stn. Res. Bull. 418.

4. Gardner, P. A., Angus, J. F., Pitson, G. D., and Wong, P. T. W. 1998. A comparison of six methods to control take-all of wheat. Aust. J. Agric. Res. 49:1225-1240.

5. Kharbanda, P. D., and Tewari, J. P. 1996. Integrated management of canola diseases using cultural methods. Can. J. Plant Pathol. 18:168-175.

6. Kirkegaard, J. A., Gardner, P. A., Angus, J. F., and Koetz, E. 1994. Effect of Brassica break crops on the growth and yield of wheat. Aust. J. Agric. Res. 45:529-545.

7. Lee, D., Hanna, W., Buntin, G. D., Dozier, W., Timper, P., and Wilson, J. P. 2004. Pearl millet for grain. Univ. Ga. Coop. Ext. Serv. Bull. 1216

8. Luttrell, E. S. 1957. Ascospore ejaculation in Gaeumannomyces graminis. Phytopathology 47:242.

9. Mathre, D. E. 1992. Gaeumannomyces. Pages
60-63 in: Methods for research on soilborne phytopathogenic fungi. L. L. Singleton, J. D. Mihail, and C. M. Rush, eds. American Phytopathological Society, St. Paul, MN.

10. McGuire, A. M. 2003. Mustard green manures replace fumigant and improve infiltration in potato cropping system. Plant Management Network. Crop Manag. Online, DOI 10:1094/CM2003-0822-01-RS.

11. Rothrock, C. S. 1987. Take-all of wheat as affected by tillage and wheat-soybean doublecropping. Soil Biol. Biochem. 19:307-311.

12. Rothrock, C. S., and Cunfer, B. M. 1986 Absence of take-all decline in double-cropped fields. Soil Biol. Biochem. 18:113-114.

13. Rothrock, C. S., and Cunfer, B. M. 1991. Influence of small grain rotations on take-all in a subsequent wheat crop. Plant Dis. 75:10501052.

14. Rothrock, C. S., and Langdale, G. W. 1989. Influence of nonhost summer crops on take-all in double-cropped winter wheat. Plant Dis. 73:130-132.

15. Shipton, P. J. 1972. Influence of stubble treatment and autumn application of nitrogen to stubbles on the subsequent incidence of takeall and eyespot. Plant Pathol. 21:147-155.

16. Smolinska, U., Morra, M. J., Knudsen, G. R., and James, R. L. 2003. Isothiocyanates produced by Brassicaceae species as inhibitors of Fusarium oxysporum. Plant Dis. 87:407-412.

17. Wilson, J. P., Cunfer, B. M., and Phillips, D. V. 1999. Double-cropping and crop rotation effects on diseases and grain yield of pearl millet. J. Crop Prod. 12:198-202.

18. Zadoks, J. C., Chang, T. T., and Konzak, C. F. 1974. A decimal code for the growth stages of cereals. Weed Res. 14:415-421.

19. Zasada, I. A., Ferris, H., Elmore, C. L., Roncoroni, J. A., MacDonald, J. D., Bolkan, L. R. and Yakabe, L. E. 2003. Field application of brassicaceous amendments for control of soilborne pests and pathogens. Plant Management Network. Plant Health Progress. Online, DOI: 10.1094/PHP2002-1120-01-RS 